\title{
Études/Inuit/Studies
}

WACHOWICH, Nancy, in collaboration with Apphia Agalakti AWA, Rhoda Kaukjak KATSAK, and Sandra Pikujak KATSAK, 1999, Saqiyuq, Stories from the Lives of Three Inuit Women, Montréal and Kingston, McGill-Queen's University Press.

\section{Edmund Searles}

Volume 27, numéro 1-2, 2003

Architecture paléoesquimaude

Palaeoeskimo Architecture

URI : https://id.erudit.org/iderudit/010826ar

DOI : https://doi.org/10.7202/010826ar

Aller au sommaire du numéro

\section{Éditeur(s)}

Association Inuksiutiit Katimajiit Inc.

\section{ISSN}

0701-1008 (imprimé)

1708-5268 (numérique)

Découvrir la revue

\section{Citer ce compte rendu}

Searles, E. (2003). Compte rendu de [WACHOWICH, Nancy, in collaboration with Apphia Agalakti AWA, Rhoda Kaukjak KATSAK, and Sandra Pikujak KATSAK, 1999, Saqiyuq, Stories from the Lives of Three Inuit Women, Montréal and Kingston, McGill-Queen's University Press.] Études/Inuit/Studies, 27(1-2), 549-552. https://doi.org/10.7202/010826ar d'utilisation que vous pouvez consulter en ligne. 
forme de changement. De plus, la prédominance de la perspective essentialist empêche aussi de saisir la dimension volontariste de tout processus de changement politique ou, en d'autres termes, de voir les différents choix et stratégies qui s'offrent aux acteurs.

Jean Rousseau

Institut en environnement, développement et société

Université Laval

Pav. De Koninck,

Québec (Québec)

Canada, G1K 7P4

jean.rousseau@fss.ulaval.ca

WACHOWICH, Nancy, in collaboration with Apphia Agalakti AWA, Rhoda Kaukjak KATSAK, and Sandra Pikujak KATSAK

1999 Saqiyuq, Stories from the Lives of Three Inuit Women, Montréal and Kingston, McGill-Queen's University Press.

As the hardback edition's dustjacket informs us, Saqiyuq means "strong wind that suddenly shifts direction." Although it is never mentioned by name in the narratives of Apphia Awa, Rhoda Katsak and Sandra Katsak (the grandmother-mother-daughter trio whose life histories form the core of this marvelous book), it is a metaphor that aptly portrays the lives of Inuit born in the last 75 years. Like a wind that changes directions, Nunavut Inuit moved off the land and into government-built settlements beginning in the mid-60s. This move exposed Inuit to a totalizing system of values, rules, and norms espoused by those controlling the settlements, the Qallunaat ("white people").

As if entering a bizarre dream, Inuit almost instantly found themselves trapped (and to some extent, protected) in a deeply foreign system of laws, routines and regulations strictly enforced by a dedicated if not idealistic group of civil servants, missionaries and educators committed to civilizing the Eskimo. Rhoda describes the situation succinctly, "when I [with her family] came off the land the people with the only type of authority were Qallunaat. The teachers were Qallunaat, the principals were Qallunaat, the RCMP were Qallunaat, the administrators were Qallunaat, the nurses were Qallunaat, it was them who told us what to do [...] " (p. 194). I was therefore startled to learn from Sandra, Rhoda's daughter, that since the early 1980s, just two decades after Qallunaat ruled everything in town, most of the teachers in Pond Inlet were now Inuit.

Such a turnaround, unimagineable when Sandra's mother was a young adult, highlights the ongoing transformation of Canadian Arctic society itself, one in which Qallunaat and Inuit share in its development and governance. A new era of Inuit professionalism is in full force now, bolstered by the creation of Nunavut as well as the expansion of numerous for profit and non-profit corporations run by Inuit, including Inuit Tapiriit Katami (ITK), Nunavut Tunngavik Incorporated (NTI), and the numerous regional Inuit associations and business development corporations. But this new phase of Inuit history is not the main focus of this book. Rather, it is the quotidian lives of 
three women connected by kinship and geography, whose experiences and perspectives Wachowich has skillfully edited and integrated into one volume.

Based on ethnographic and historical accounts of the lives of Inuit during the decades of upheaval and dislocation, it is clear that Apphia, Rhoda and Sandra, like many Inuit, view this period of history with considerable ambivalence and even confusion. The confusion stems from the fact that Inuit are not sure if access to money, public education, and modern conveniences has made their lives better or worse. Was life better before the Qallunaat arrived? Was it worse? Was it both? Two realms of knowledge and subjectivity, one linked to imagining the present, the other to imagining the past have emerged as key and inseparable components of an emerging Inuit historical consciousness and cultural identity.

The past and present are intertwined because Qallunaat ushered in both a new way of living in the present and a new way of thinking about the past. Missionaries and nonInuit educators introduced a version of world history in which Inuit were neither prominent nor relevant. But this modification of historical consciousness also reshaped Inuit attitudes about the present and the future. Rhoda admits that she grew up thinking that she should try to be Qallunnat, and that is why she had Qallunaat idols like the Supremes and Elvis Presley (p. 195). The adoption of popular icons and aspirations of mainstream Qallunaat society not only influenced Inuit to rethink their future, but it created a history in which Inuit heros and villains were either absent or relevant, replaced by Qallunaat heros and events, like Martin Frobisher and his "discovery" of Baffin Island in 1576.

A central unifying theme of the narratives of these three women is the complex ways in which they wrestle with their historical consciousness, a process that is neither simple nor predictable. Rhoda's soulful confession at the end of her memoir reveals that a sustained gaze into her own life history has generated more questions than answers. "Why did I spend almost all of my life trying to get away from it [Inuit tradition and culture] [...] It's like they [Qallunaat] spent all those years trying to change me into a Qallunaaq and they couldn't. Was my life wasted?" (p. 200). Such honest ambivalence strikes me as a key component in the ongoing aspirations of Inuit as they struggle to reclaim their past and their present.

At one point in the book, Apphia, Rhoda's mother, evidences remarkable certainty about the past when she describes it within the context of her life-changing experience of becoming a Christian in 1985. She describes this event as one of the most important events in her life, one that transformed her worldview and saved her from a past characterized by "deepest, darkest sin" (p. 139). This comes as somewhat of a surprise to the reader, in part because we learn that Apphia was baptized into the Anglican Church by a missionary in 1967 at the age of 36. Apparently, she did not identify too strongly with her baptism nor fully understand its implications. But Apphia's faithinspired confession about the past is also surprising because it so blatantly contradicts the previous 130 pages of her testimony. Although she describes being fearful and confused as a child and later as an adult, she also carefully documents many acts of generosity, empathy, and humility, traits even the most zealous Christian would be 
hardpressed to identify as the work of deepest, darkest sinners. In short, aside from her proclamation on p. 139, Apphia's view of the past is strikingly complex. At one point, she describes how well she and her husband were able to endure the hardships of arranged marriage, childbirth without doctors or nurses, and periods of sickness and hunger with courage and resolve: "When we were living it [marriage], when we were doing it [living as a married couple], it was all right. Happiness was around us. There didn't seem to be all that many stressful situtions" (p. 42). And even this devout Christian cannot hide her contempt for capitalism, brought to Inuit and later reinforced by the activities of specific Qallunaat, including missionaries. Apphia states: "Qallunaat want things to be paid for right away. I do not like this business of paying for something that you get from your relatives. It makes me sad, very sad [...] I don't know where they [her family members] learn that there is a cost to everything" (p. 133134).

Sandra, echoing the sentiments of her grandmother, is discouraged by the presence of socially and culturally destructive appetites for fast food, television and cigarettes that are the hallmark of youth culture in Pond Inlet. At one point she wonders "what the feeling would be like not to be dependent on Qallunaat things. I always tell elders that they were lucky that they grew up that way, in kamiks and skins" (p. 224). Ironically, her enthusiasm for learning about life prior to the presence of Qallunaat is harshly rebuffed by the elders themselves, who invariably "[...] say negative things about back then. They talk about having lice in their hair, or they say it was too cold" (p. 224).

Taken in pieces, the ambivalence, confusion and complexity one finds in the life histories of Apphia, Rhoda and Sandra would seem to be emotionally and morally destructive, both to individuals and to the group they belong to. When viewed as an interconnected and overlapping pattern of life histories, however, these stories reveal much continuity and unity, particularly with regard to a desire to confront the past in order to reshape the present and the future. Seen in this light, ambivalence towards the Qallunaat-induced transformation of Inuit society has inspired a new found commitment to revising popular constructions of the past and reimagining how to live in the present. These are the seeds, I think, of a new wave of intellectual vitality and political activism that will keep Inuit tradition and identity relevant in an age of expanding corporatization and mass consumption.

Another strength of the book is that it exposes the benefits of cooperation and collaboration between anthropologists and informants, which is refreshing given much recent criticism about the exploitation of indigenous peoples on the part of researchers. Wachowich admits that in editing and arranging the stories for publication, she was careful to preserve their voices and narrative styles. That being said, I myself was frustrated with the paucity of analysis and exegesis, particularly in light of recent transformations in Inuit society. When compared to their peers in other regions of the Arctic, are the experiences of Apphia, Rhoda and Sandra typical, atypical, neither or both? Why or why not? What do these stories say about Inuit culture, identity and gender-do they confirm or undermine stereotypes? Where do these narratives fit in an emerging canon of subaltern autobiographies written by women of color growing up in the shadow of repressive colonial and neocolonial regimes? Looking back, however, 
I think of the absence of critical analysis not so much a weakness but an important challenge to future researchers. We should think of these life stories not as a conclusion but as the foundation for future discussions and inquiries into Inuit ideas about memory, history and identity.

Another issue these stories raise is the question of authorship. Based on Wachowich's description of her role in the collection, transcription and final editing of these women's stories, I am confused by her claim as being the primary author of Saqiyuq. Even with the addition of an introduction, endnotes, and an overview (all written by Wachowich), Saqiyuq is primarily a collection of stories by three Inuit women. This is its main strength and its most important contribution to the study of Inuit. Wachowich should be credited with bringing these stories to press, and editing them, but not with being the primary author of these stories.

These criticisms aside, this book is essential reading for anyone working in the field of Inuit Studies. It is particularly suitable for undergraduate classes focusing on anthropology, biography, folklore, ethnohistory, history, indigenous peoples, gender, and of course, Inuit Studies or for anyone teaching methodology (graduate and undergraduate levels) in the social sciencees. The life histories of Apphia, Rhoda and Sandra provide a badly needed corrective to the legacy of one-dimensional portraits of Inuit encountered in copious explorer and adventure memoirs. In Saqiyuq one finds not caricatures but complex characters whose lives are richly textured and whose stories are at once compelling, disturbing and stimulating. Perhaps this style of juxtaposing life histories is the beginning of a new tradition of Inuit literature.

Edmund Searles

Department of Sociology and Anthropology

Bucknell University

Lewisburg, PA, USA

esearles@mail.bucknell.edu

THORPE, Natasha, Naikak HAKONGAK, Sandra EYEGETOK and the Kitikmeot Elders

2001 Thunder on the Tundra: Inuit Qaujimajatuqangit of the Bathurst Caribou, Vancouver, Tuktu and Nogak Project, 208 pages.

Thunder on the Tundra not only describes the need for collecting Inuit Qaujimajatuqangit (or traditional knowledge), but provides a shining example of how to present such information. Whether in the Kitikmeot Region, the Mackenzie Delta, the Deh Cho Region, or Palawan Island in the Philippines, where I had the time to really read and reflect on this work compiled by Natasha Thorpe, Naikak Hakongak, Sandra Eyegetok, and the Kitikmeot elders, it is evident that we have only a short window of time in which to acquire and record traditional ecological knowledge.

The timeliness of this work cannot be overstated. Elders in Northern Canada, like elders of Aboriginal people in other parts of the world, are passing away and with them 